\title{
\begin{tabular}{|ll} 
JCAU \\
J
\end{tabular}
}

\section{Street Network: Physical and Cultural Transformations on the Morphology of Historical City of Malacca}

\author{
Marina Mohd Nor ${ }^{1}$, Norzailawati Mohd Noor ${ }^{1}$, Sadayuki Shimoda ${ }^{2}$ \\ ${ }^{1}$ Urban and Regional Planning Department, Kulliyah of Architecture and Environmental Design, \\ International Islamic University of Malaysia, 53100, Selangor, Malaysia \\ ${ }^{2}$ Architecture and Civil Engineering Department, Kumamoto National College of Technology, \\ Yatsushiro City, Kumamoto, Japan
}

Corresponding author: Marina Mohd Nor, Urban and Regional Planning Department, Kulliyah of Architecture and Environmental Design, International Islamic University of Malaysia, 53100, Selangor, Malaysia. Email: marina.mn@gmx.com

Citation: Mohd Nor M, Mohd Noor N, Shimoda S, 2020, Street Network: Physical and Cultural Transformations on the Morphology of Historical City of Malacca. Journal of Chinese Architecture and Urbanism, 2(2): 972. http://dx.doi.org/10.36922/jcau.v2i2.972

\begin{abstract}
The deterioration of streets in the historical city of Malacca in Malaysia due to modernization contributes to the streets' vulnerabilities. This paper purposely analyses the physical transformation of the street networks for the years of 1993-2015, and the cultural influences and impact throughout the establishment of multi-racial cultural society. The methodology for the study is through mapping the street networks of Malacca city by using SPOT satellite imageries of three different years; 1993, 2005, and 2015, and through the street semi-automatic extraction technique to monitor the street pattern of Malacca city. Multiple sensors of SPOT were used, consisting of SPOT-2XS, SPOT 5, and SPOT 6 with $20 \mathrm{~m}, 5 \mathrm{~m}$, and $1.5 \mathrm{~m}$ resolutions in extracting the street objects, while using the IMAGINE OBJECTIVE tools from ERDAS. The finding shows that the street network trend varied from 1993, 2005, and 2015 where the streets achieved $23.8 \%$ street expansions in the year 1993 compared to $10.49 \%$ in the year 2005. However, the development trend of streets increased to $14.68 \%$ in the year 2015 . The connection of the physical transformations of the streets with the cultural impact contributed to the sense of place and divided the streets based on socio-economic, cultural and ethnic lines. Finally, it shows that the trend and pattern of street networks were essential in understanding a city's morphology that has a significant impact on cultural evolution since the establishment of the Chinese community in Malacca.
\end{abstract}

Keywords: satellite extraction, SPOT, street network, Chinese society, Malaysia

Copyright: $(2021$ Mohd Nor, et al. This is an open-access article distributed under the terms of the AttributionNon-Commercial 4.0 International 4.0 (CC BY-NC 4.0), which permits all non-commercial use, distribution, and reproduction in any medium provided the original work is properly cited. 


\section{INTRODUCTION}

Transformation and formation of urban areas known as urban morphology has become an exciting topic in understanding spatial structure and characteristics of historic cities such as Malacca in Malaysia. The study and analysis that focus on the street pattern are essential to understanding how the physical forms of a city change over time, and how different cities compare to each other ${ }^{[1,2]}$. Street network is an expanding and permanent physical aspect in cities, which are unalterable and have a strong influence on physical and cultural transformations to urban growth. This transition of the city from the past to the present condition describes the process of urban growth, which impacts settlement form and structure ${ }^{[3-5]}$. Therefore, urban morphology becomes an essential key of urban development for understanding the transformation and evolution of the urban fabric. In this study, one of the elements in urban morphology, street network, will be analyzed to understand the morphology of the city's physical development, and how it relates to the cultural transformation and establishment of a Chinese society in Malacca. The founding of a Chinese society was through a good relationship with China during Malacca's recognition as a famous trade port, when a stronger relationship between China-Malacca was built in 1403 . Measuring the street network pattern helps researchers, planners, and communities understand the city's local histories ${ }^{[6,7]}$. Thus, this article attempts to fill the gap in understanding the correlation between physical transformation and cultural influences throughout the establishment of a Chinese society in Malacca, one of the most historical cities in Malaysia. Street semiautomatic extraction analysis from the years 1993, 2005, and 2015 will be analyzed with the help of current technologies such as GIS and remote sensing. This technological approach can reveal the relationships of urban pattern and trend, reflecting the time factor and how the cities resulted from the long process of construction ${ }^{[8-10]}$.
Meanwhile, the literature review part works as a proxy of the interrelation between physical and cultural transformations. This study is essential as it provides a better understanding of the street network pattern and how it corresponds to the evolution of culture that shaped the underlying structure of the city. Besides, it can also reveal the connection of various cultures, including Chinese business activities, in the street functions of the study area. The study was guided by the main research question: how the morphology of the street network influences the cultural transformation in Malacca city? A particular focus was given to Chinese society as this group first settled down in Malacca city ${ }^{[11]}$.

\subsection{China-Malacca trade relationship}

The establishment of a Chinese community in Malacca began for two reasons. First, the relationship between Malacca and China was for trade and protection from Majapahit and Siam. Second, it was because of the historic marriage of Sultan Mansur Shah (Sultan of Malacca; 1456-1477) and the daughter of a Ming Emperor, Princess Hang Li Po. The princess came with her 500 attendants, and the attendees married the locals and started their communities ${ }^{[12-14]}$. Due to these events, many Chinese came and settled down through intermarriages with the locals and formed the Baba-Nyonya communities or Peranakan Chinese. According to Seok-Joon (2016), Malacca was the first city where the Chinese began to settle down ${ }^{[11]}$. Thus, the cultural diversity, complexity, and hybridity have led Melaka to be a "Historic and Cultural City" according to the Government 1992 [15]. During the Portuguese period (1511-1641), only a few members of the Chinese lived in Malacca. In the Portuguese map of the 16th century, there was a Chinese settlement called Kampung Cina, and the first Chinese Temple known as Cheng Hoon Teng Temple was founded by Chinese Captain Zheng Fang-yan ${ }^{[16]}$. Chen Hoon Temple is the oldest temple in the country ${ }^{[11,14,17]}$ [Figure 1].

During the Portuguese (1511-1641) and Dutch (1641-1826) occupations, they 
appointed the Chinese, Li Jun Chang, as Kapitan (Captain), who founded the city's first Chinese Temple and acquired Bukit (Hill) China for the community [18]. In the early 1800s, Chinese economic activities increased that led to a massive influx of Chinese settlers. Because of this, most of the Peranakan lived in several streets adjacent to the river, including Heeren Street, Jalan Hang Jebat, Blacksmith Street, Goldsmith Street, and Temple Street [Figures 2 and 3]. Majority of the house designs reflected Dutch and Chinese architectural styles. In his book Melaka on Top, Dennis (2010) recounts that Blacksmith Street, Goldsmith Street, and Temple Street were traders' quarters since the Sultanate period ${ }^{[19]}$. Then, from time to time, the communities comprised of five multiracial communities: Straits Chinese (Baba Nyonya), Straits India (Chitty), Indian, Serani, and Javanese-Malay. Since the British period (1826-1957), the Chinese community mainly occupied and became Malacca's Chinatown. These streets were called Harmony Streets, due to several religious buildings on the same stretch of streets [Figure 4]; Kampung Kling Mosque, Sri Poyyatha Vinayaga Moorthy Tempel, and Cheng Hoon Teng temple.

Chinese became a dominant ethnic group, and the numbers of Baba and non-Baba increased. The population continued to grow during British colonization in the $19^{\text {th }}$ century. The Peranakan Chinese or Baba and Nyonya comprehended the Malay community, which could be seen from their adaptation of the local culture, language, clothing, jewelries, singing, and poetry ${ }^{[13]}$. From this, it can be assumed that the Sultanate Malacca period's trading relations played a significant role in establishing and forming a new ethnic group, the Peranakan Chinese community in Malacca ${ }^{[18]}$ [Figure 5].

\section{RESEARCH METHODOLOGY}

In this study, street network analysis was conducted to analyze people's influence, culture, and movement from a particular period. It corresponds with the socioeconomy of Malacca, known as the maritime port, and how it is associated with the development of streets and townscapes of the city. Malacca state is located next to the Straits of Malacca, at the coordinate location of 2.200844 latitudes and 102.240143 longitudes [Figure 6], known as the longest international route through a strait and linked with the straits of Singapore. The Malacca Straits have long been an important trade route linking the Indian Ocean to the South China Sea and the Pacific Ocean. Due to its strategic location, Malacca has become an important port during the $15^{\text {th }}$ century and was influenced by the British settlement during British colonization. The historic city center has been listed as a UNESCO World Heritage site since 7 July 2008. The historic center of Malacca comprises two zones: Core Zone and Buffer Zone, including Sungai Melaka that passes through the site. The core zone, which encompasses St Paul's Civic Zone and Historic Residential and Commercial Zone ${ }^{[20]}$, is defined as the most protected area that compromises every aspect of biological diversity, maintenance, and services in provisioning, regulating, and cultural services.
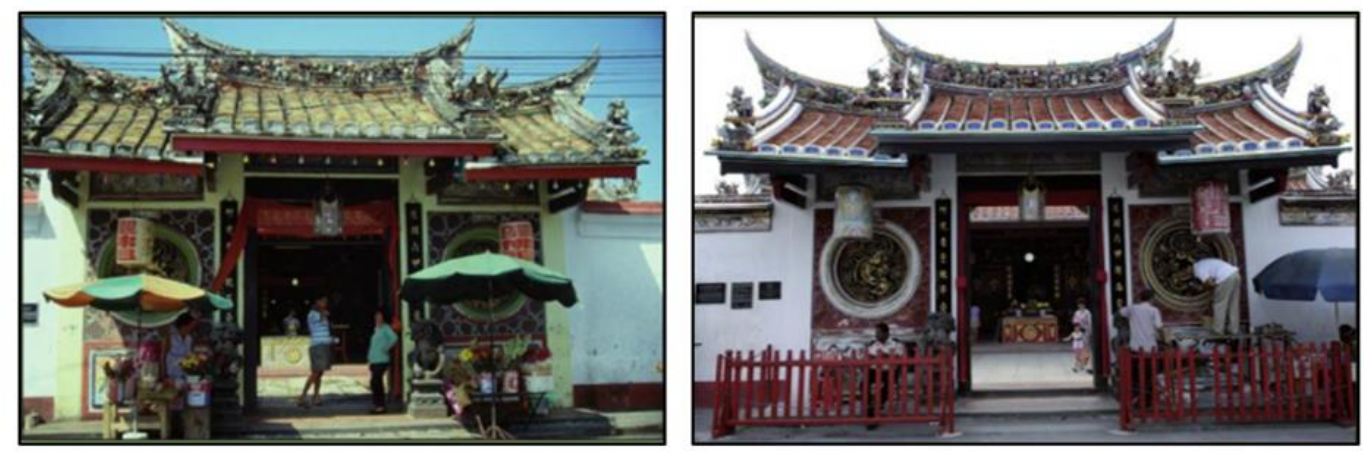

Figure 1. Cheng Hoon Teng Temple in 1990 (left) and current view after restoration (right). Source: Photos by the author 

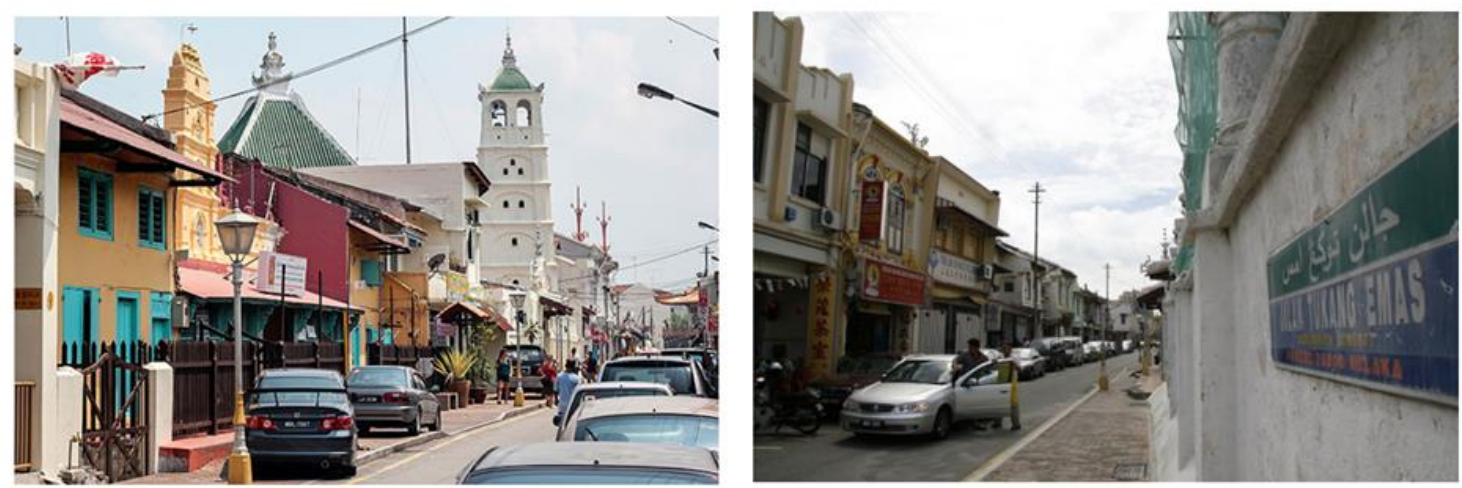

Figure 2. Jalan Tokong or Temple Street (left) and Jalan Tukang Emas or Goldsmith Street. Source: Photos by the author, 2018
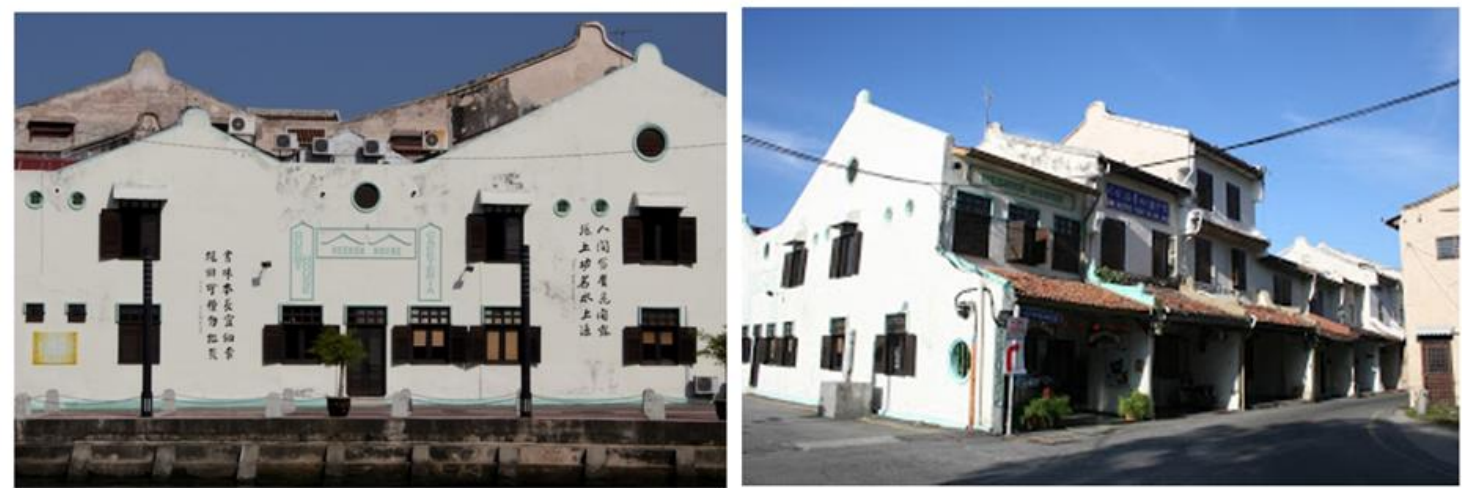

Figure 3. Heeren Street was laid during the Dutch occupation in the 1700s and located along the Sungai Melaka. Source: Photos by the author, 2018

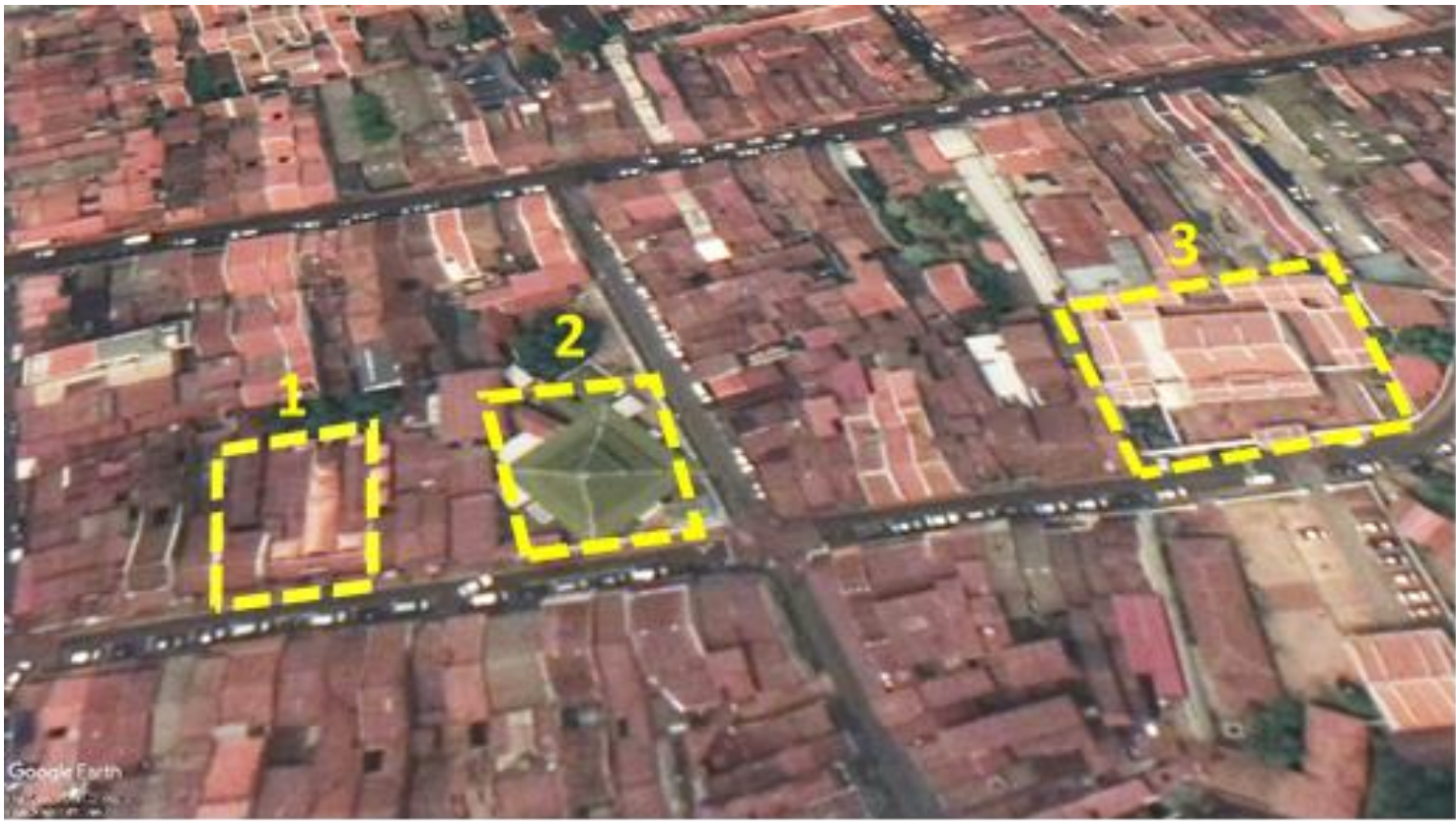

Figure 4. Aerial view of the religious building along the Harmony Street: (1) Sri Poyyatha Vinayaga Moorthy Tempel, (2) Kampung Kling Mosque, and (3) Cheng Hoon Teng temple. Source: Google Earth, 2021 


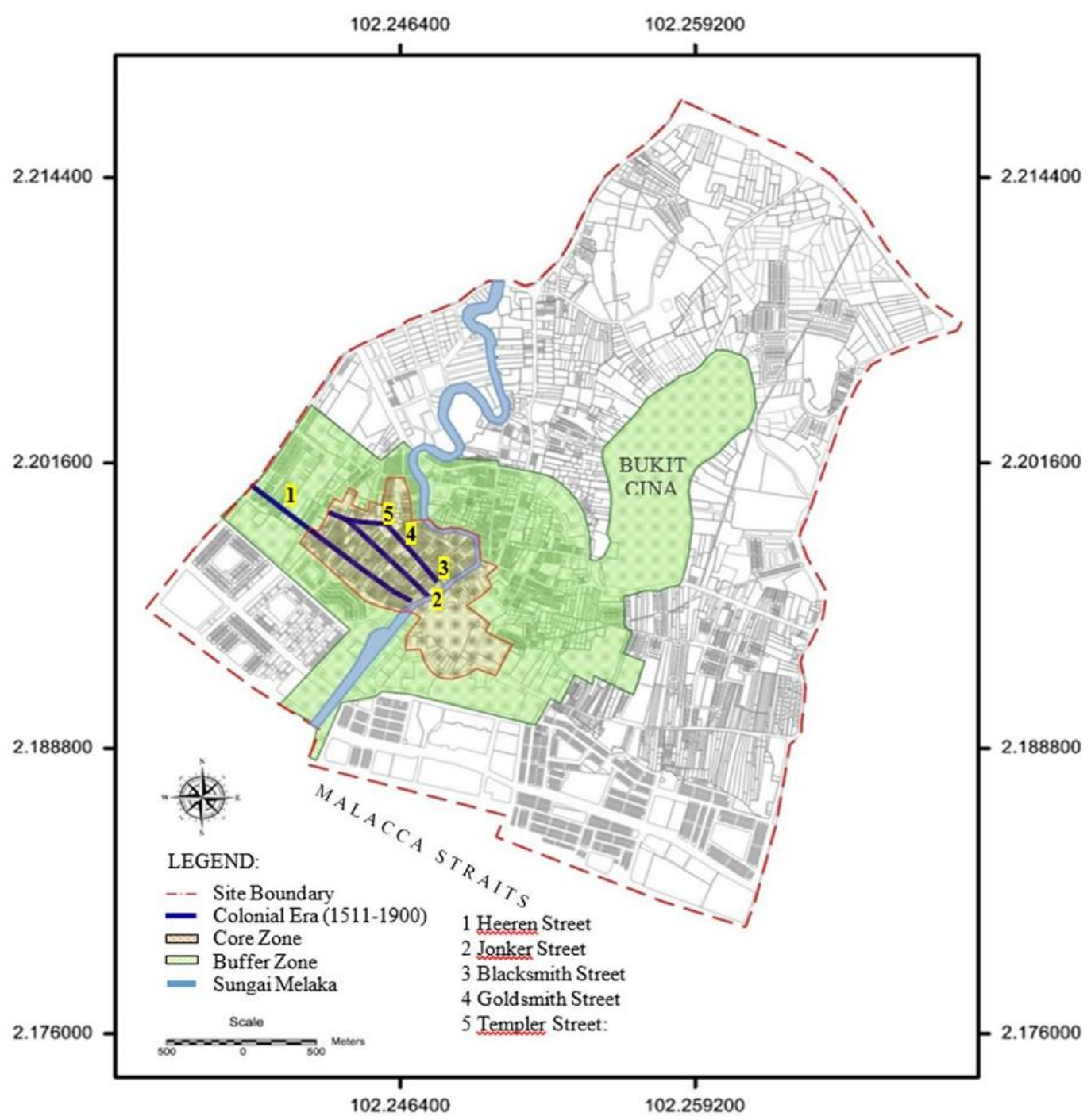

Figure 5. The Chinese Settlement in the inner Historic Malacca. Source: Map by the author, 2018

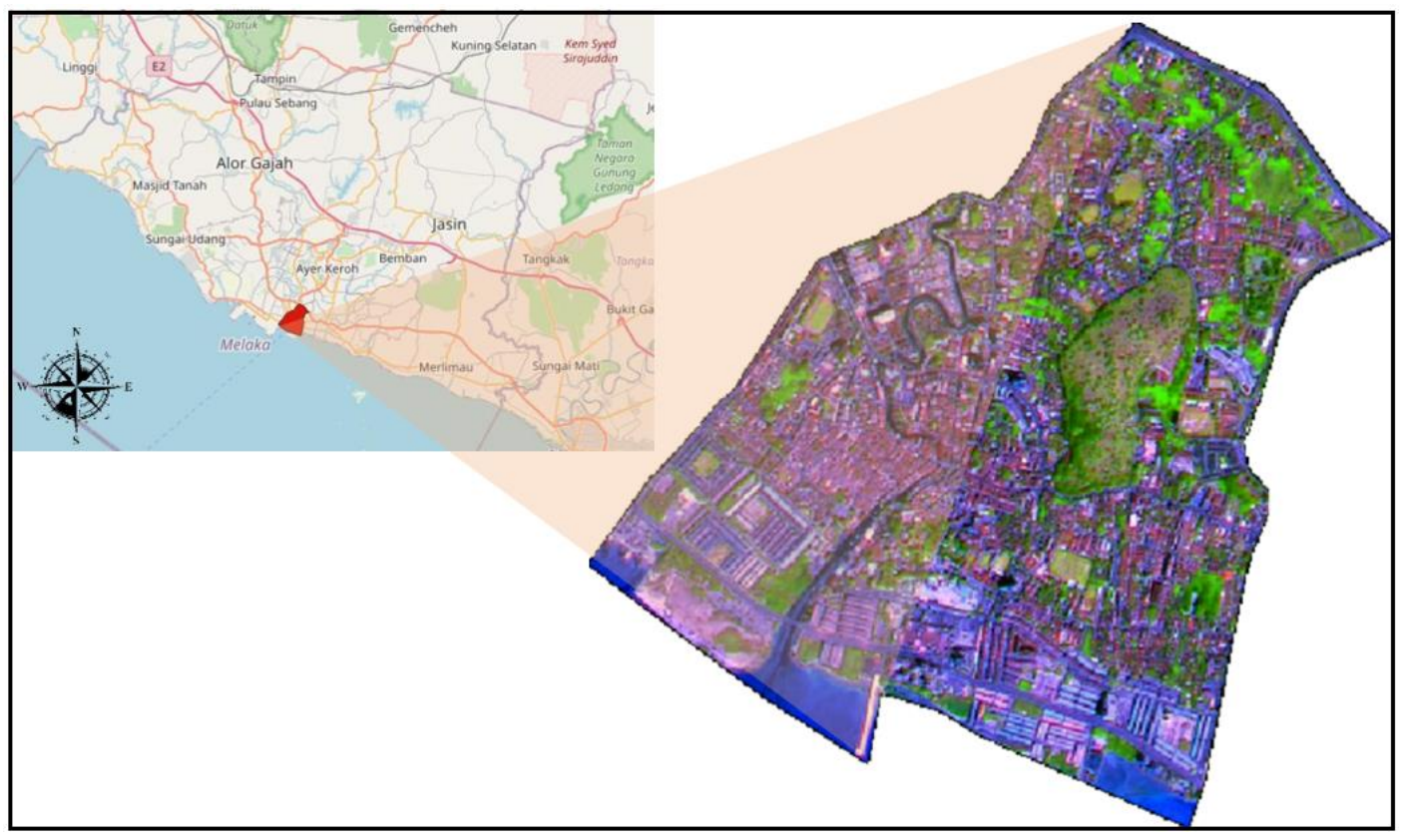

Figure 6. Location of the study area. Source: Drawing by the author, 2018 
Meanwhile, buffer zones are created to enhance specific areas. It surrounds the core areas and helps to reduce the impact of human activities at the core. Malacca city is an urban historic place that has become a 'must-see' in Malacca. It has a mixture of heritage attractions corresponding to its status as one of the World Heritage sites. As a historic city, Malacca has developed over 500 years of trading and cultural exchanges between East and West along the Straits. The influences of Asia and Europe have endowed the city with a specific multicultural heritage that is both tangible and intangible ${ }^{[21]}$.

\subsection{Material}

For the street network morphology study, three temporal and different versions of SPOT platform $2 \mathrm{XS}, 5$ (MS), and 6 (MS) level 3 in the years of 1993, 2005, and 2015 were used to extract a street network pattern and to analyze the changes in the pattern. The detailed satellite data collected for the study is listed in Table 1.

All the data in digital form were readily used in data processing in Digital Image Processing. ERDAS IMAGINE 2014 was used to analyze the morphology of the street network by extracting the street category. The formation of street network in the study area were monitor based on the years of 1993, 2005, and 2015. Subsequently, the influence and evolution of the streets in 22 years were determined.

\subsection{Methods}

The selection and representation of road information for the study area is critical. In general, the road information from SPOT is described as follows; road objects generated by image segmentation present a relatively homogenous grey, showing a certain level of contrast with the surrounding background. Street extraction using IMAGINE Objective in ERDAS IMAGINE software has been used to segment the streets from the background. The objective of extracting street network is to classify the different spectral value of streets and non-streets. This is because some features such as building or pavements have the same material and spectral reflectance as the streets. The semi-automatic method was applied to segregate and differentiate the objects according to two categories of street and non-street. Therefore, human knowledge is vital to differentiate and correct the identification of objects. The categorization of the streets and non-streets were carried out through training seeds, and it would help to classify the whole image into only two classes: streets and non-streets. Fifty (50) training seeds have been selected in streets pixel and classified as streets group, and others with different spectral reflectance than streets fall into the non-streets group.

Three SPOT satellite images of the years 1993, 2005, and 2015 have been generated through the processing in the IMAGINE Objective. Raster Object Creators (ROC) process node was adopted to carry out all possible street pixels/objects to street raster objects using Threshold and clump operator. A further reduction in non-street raster must be applied in Raster Object Operator (ROO). Several options on the operator can be used, such as a size filter that will remove tiny objects. The centerline convert operator will convert all possible street raster objects into linear raster objects with single-pixel/object width for road extraction. The line trace operator will convert centerline objects to vector objects in Raster to Vector Conversion (RVC) process node. Finally, Vector Object Operators (VOO) can finalize the road network demand based on the series of operators that need to use, such as Line Link, Smooth, Line Snap, and Ribbon Remove. The series of VOOs can be adjusted by changing the parameters or rearrange the process nodes to carry out the final vector of the street network in the study area [Figure 7]. 
Table 1. Material for this study

\begin{tabular}{lcccccc}
\hline Data types & Year & $\begin{array}{c}\text { Spatial } \\
\text { resolution }\end{array}$ & $\begin{array}{c}\text { Spectral } \\
\text { band }\end{array}$ & $\begin{array}{c}\text { Level of } \\
\text { processing }\end{array}$ & $\begin{array}{c}\text { Acquisition } \\
\text { data }\end{array}$ & Path/row \\
\hline SPOT-2 XS & 1993 & $20 \mathrm{~m}$ & 4 bands & Ortho Level 3 & 17 Feb 1993 & $271 / 346$ \\
\hline $\begin{array}{l}\text { SPOT 5 } \\
\text { Pansharp }\end{array}$ & 2005 & $5 \mathrm{~m}$ & 4 bands & Ortho Level 3 & 20 Jan 2005 & $272 / 346$ \\
\hline $\begin{array}{l}\text { SPOT 6 MS } \\
\text { Pansharp }\end{array}$ & 2015 & $1.5 \mathrm{~m}$ & 4 bands & $\begin{array}{c}\text { Raw R sensor } \\
\text { Pansharp }\end{array}$ & 3 Dec 2015 & $\begin{array}{c}\text { AOI } \\
\text { Bandar Malacca }\end{array}$ \\
\hline
\end{tabular}

Source: Table by the author, 2018
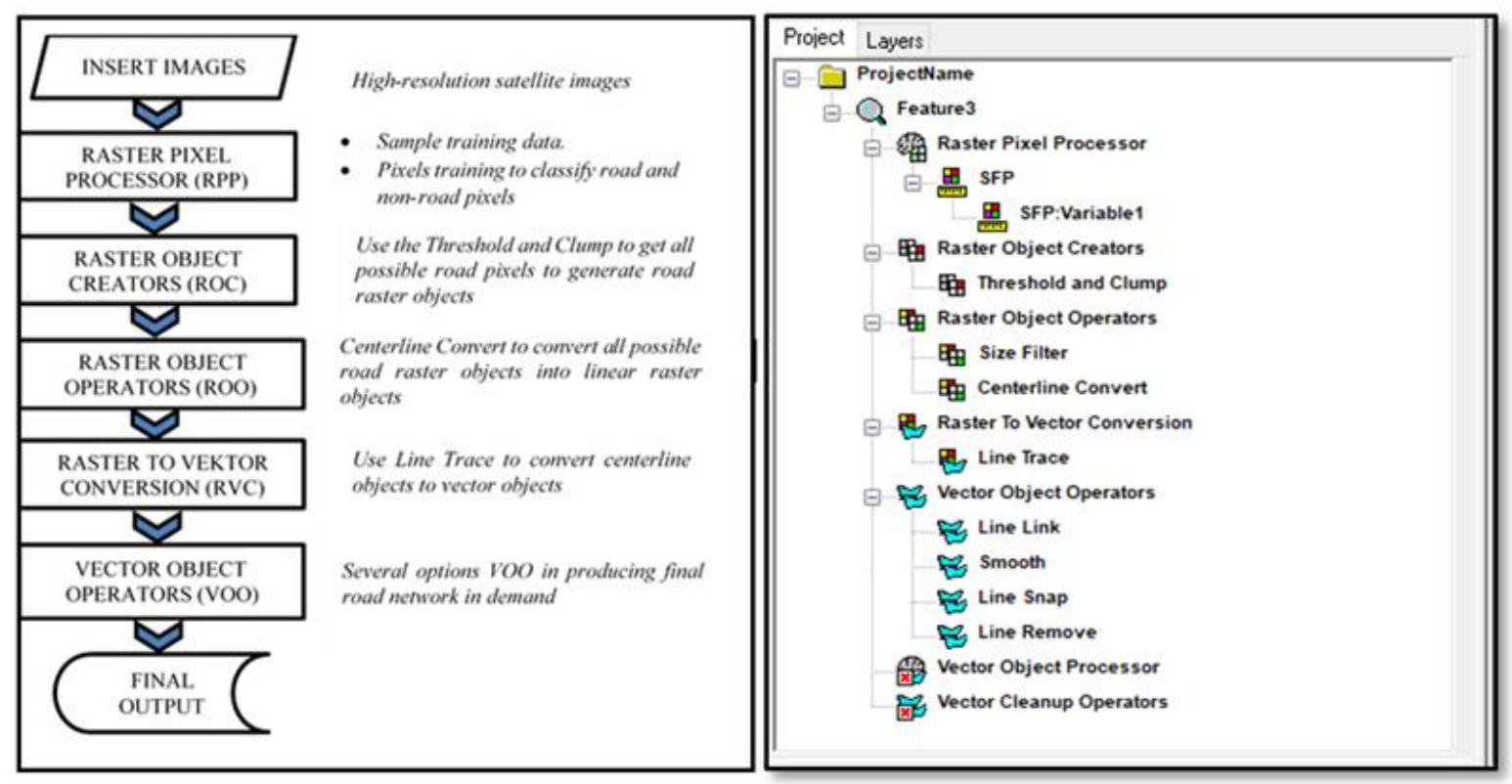

Figure 7. Basic road extraction flowchart adopted in this study (left) and features model of street extraction (right). Source: Chart by the author, 2018

\section{RESULT AND DISCUSSIONS}

This section discusses the result of the study concerning the physical and cultural transformations of the historic city of Malacca. The evolution of the street network from 1993 to 2015 can be seen from the physical transformation, where the street network pattern evolved from time to time to follow the demand of the development. The cultural transformation is part of the impact factor that influences the street setting, which has different community backgrounds, including Malay, Indian, and Chinese settlement. The impact of the cultural movement of the study is primarily focusing on the existing Chinese community that has contributed significantly to the development of Malacca.

\subsection{The expansion of the street network}

The result of street extraction applied to three types of multi-temporal SPOT imageries shows that the street features have been extracted with good quality SPOT 5 and 6 , and a little low quality for SPOT 2 . Figure 8 shows the result of the street extracted for the SPOT 6 image for the year 2015. 

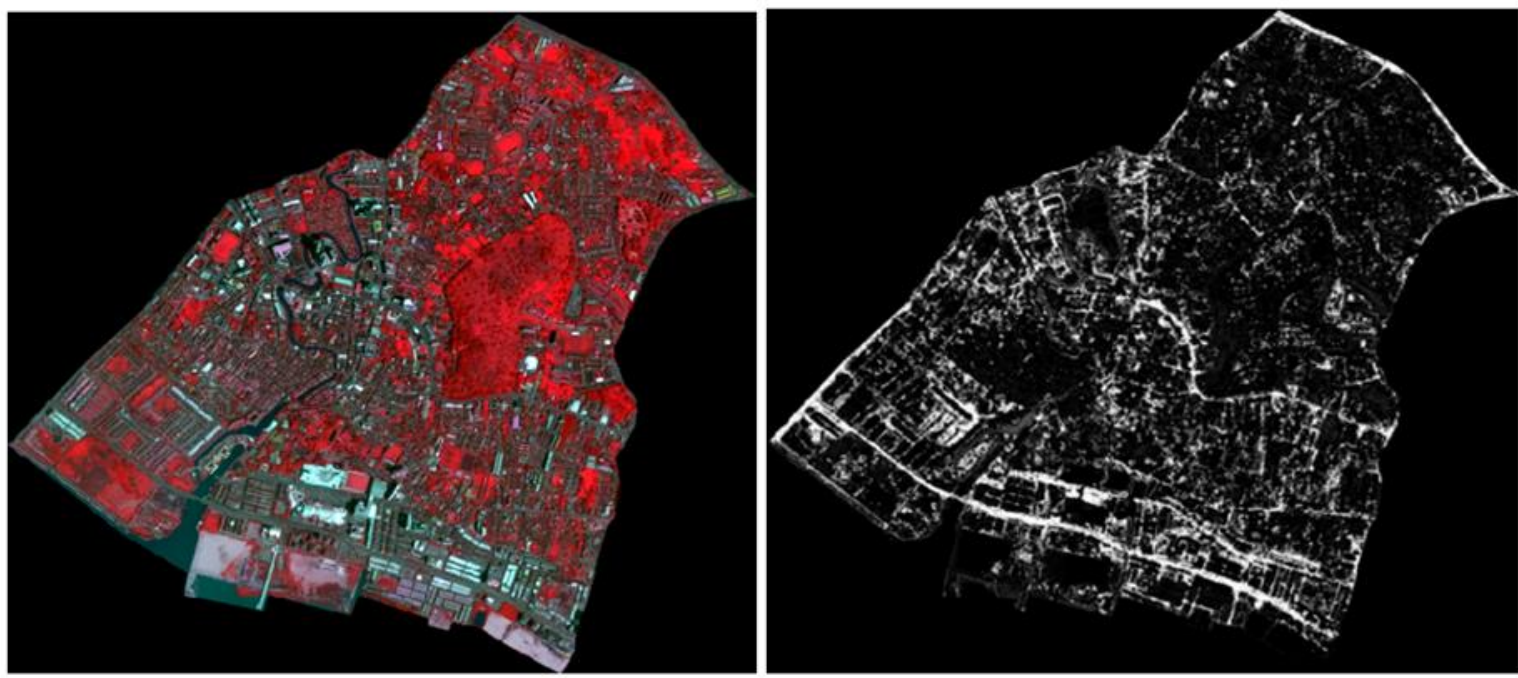

Figure 8. The original image of SPOT (left) and the result of street extraction (right). Source: Images by the author, 2018

Figure 9 shows the overall visualization analysis for street extraction in 1993, 2005, and 2015. The accuracy assessment for the classification for the year 1993 is $93 \%$, the year 2005 is $85.71 \%$, and the year 2015 is $94.44 \%$. The overall percentage of classification is more than $80 \%$, and it is considered acceptable. However, for the year 1993 street extraction, we found that the result is not very precise where the algorithm of the street cannot be seen precisely compared to 2005 and 2015. The accuracy assessment process is crucial. It can be defined as "the degree of correctness" that measures the agreement between a standard assumed to be a correct and classified image of unknown quality. According to Foody (2002), image classification accuracy refers to the extent to which it agrees with a set of reference data ${ }^{[22]}$. Thus, the constraint to obtain the data with medium-resolution for the year 1993 can be detected based on sample training using the Single Features Probability (SFP) function in IMAGINE Objective tools representing the hardness of features segmentation in IMAGINE Objective tools the medium resolution of 20-meter SPOT 2 image.

Figures 10 and 11 show the transformation of street network patterns for 22 years. The movement of the street network was developed from the inner city to the coastal area. In the year 1993, the development of the city was slow compared to the year 2015, which shows that the newest development was triggered over the Malacca straits. The street network spatial distribution can be clearly seen in the plotting on the graph [Figure 11]. The overall distribution of the street network pattern shows that newer street network was developed from time to time.

Moreover, the street development was concentrated on the surrounding constant points: Kota A Famosa, Clock Tower, Temple Sri Poyyatha and Jonker Street. Thus, the establishment of new development in the reclaimed area has contributed to a new street network that connects to the existing street at the core area of Bandar Hilir. New commercials were built, which have generated social activities in the street. Besides, the development plan published by Melaka State Government prohibited any new development in the core and buffer areas to preserve and conserve the existing heritage buildings. If this is violated, it will cause UNESCO to withdraw the title of Malacca as a historic city. It assumes that the street network pattern was expanding from the existence of Malacca during Sultanate Malacca until the present. The settlement started along Sungai Melaka, where the influx of migrants came in and the trading port grew in Malacca. The streets began to exist, including Heeren Street, Jonker Street, Blacksmith Street, Goldsmith Street, and Temple Street. The Malacca streets were 
named after nature in the area. As Rahman et al. (2015) mentioned, the street characteristics differ according to the purpose and function of their locations, physical forms, and presence, including the cultural backgrounds of the users ${ }^{[23]}$.
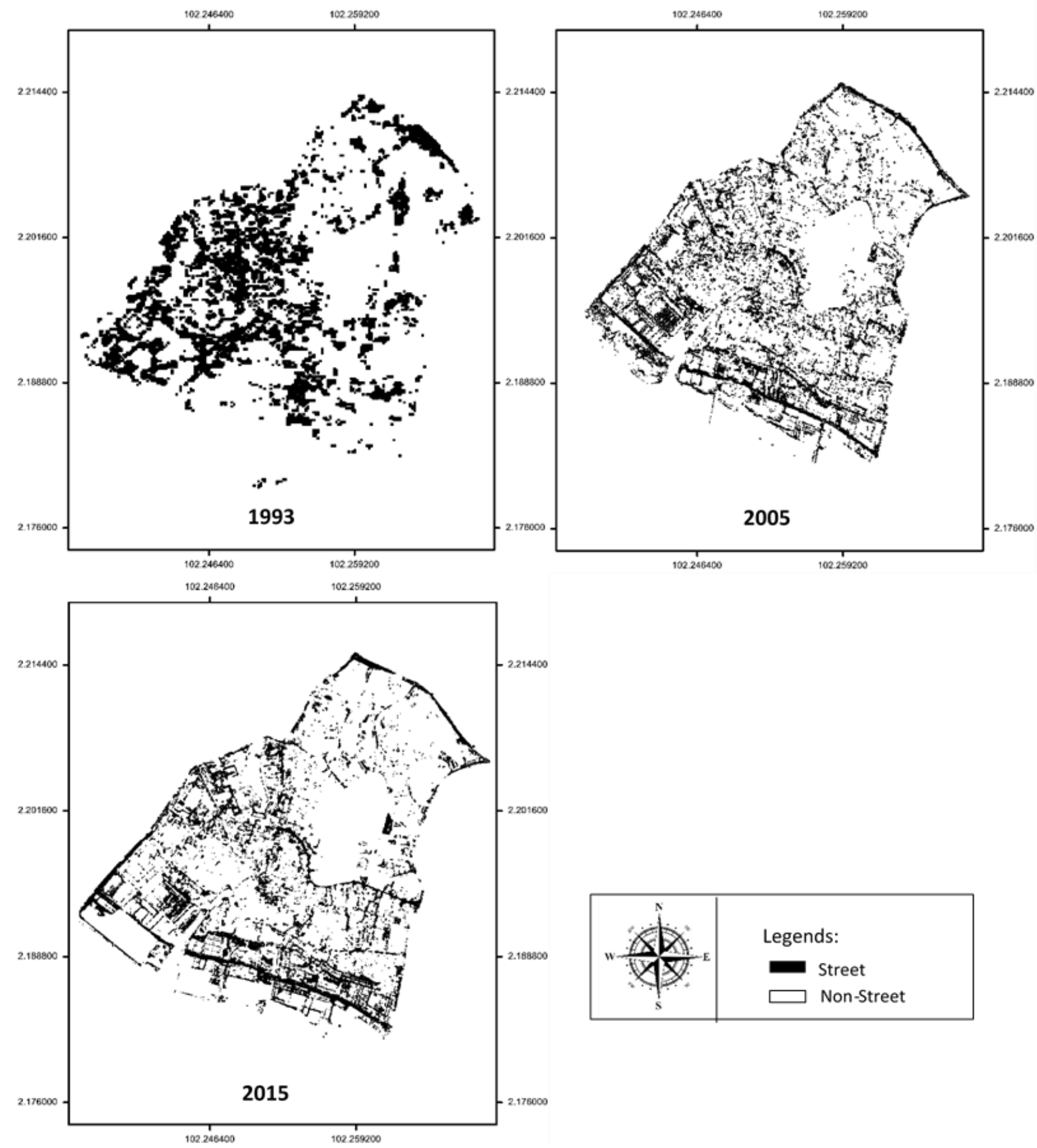

Legends:

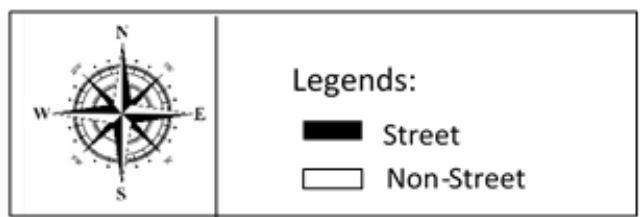

Figure 9. Result of road extraction showing the street and non-street data obtained from the multi-temporal SPOT image. Source: Map by the author, 2018 


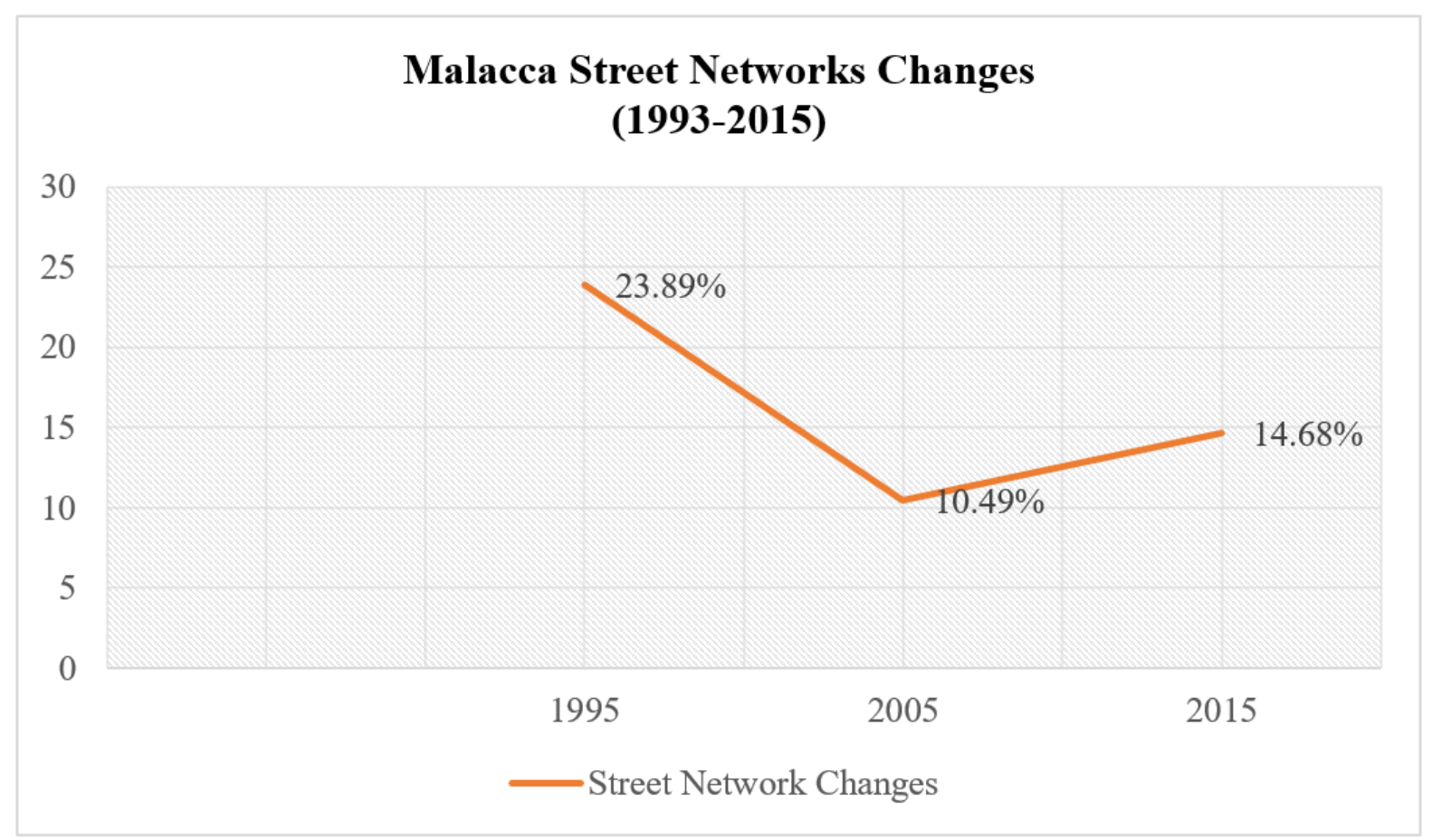

Figure 10. Percentage of street network changes in the study area for 1993, 1995, and 2015. Source: Graph by the author, 2018
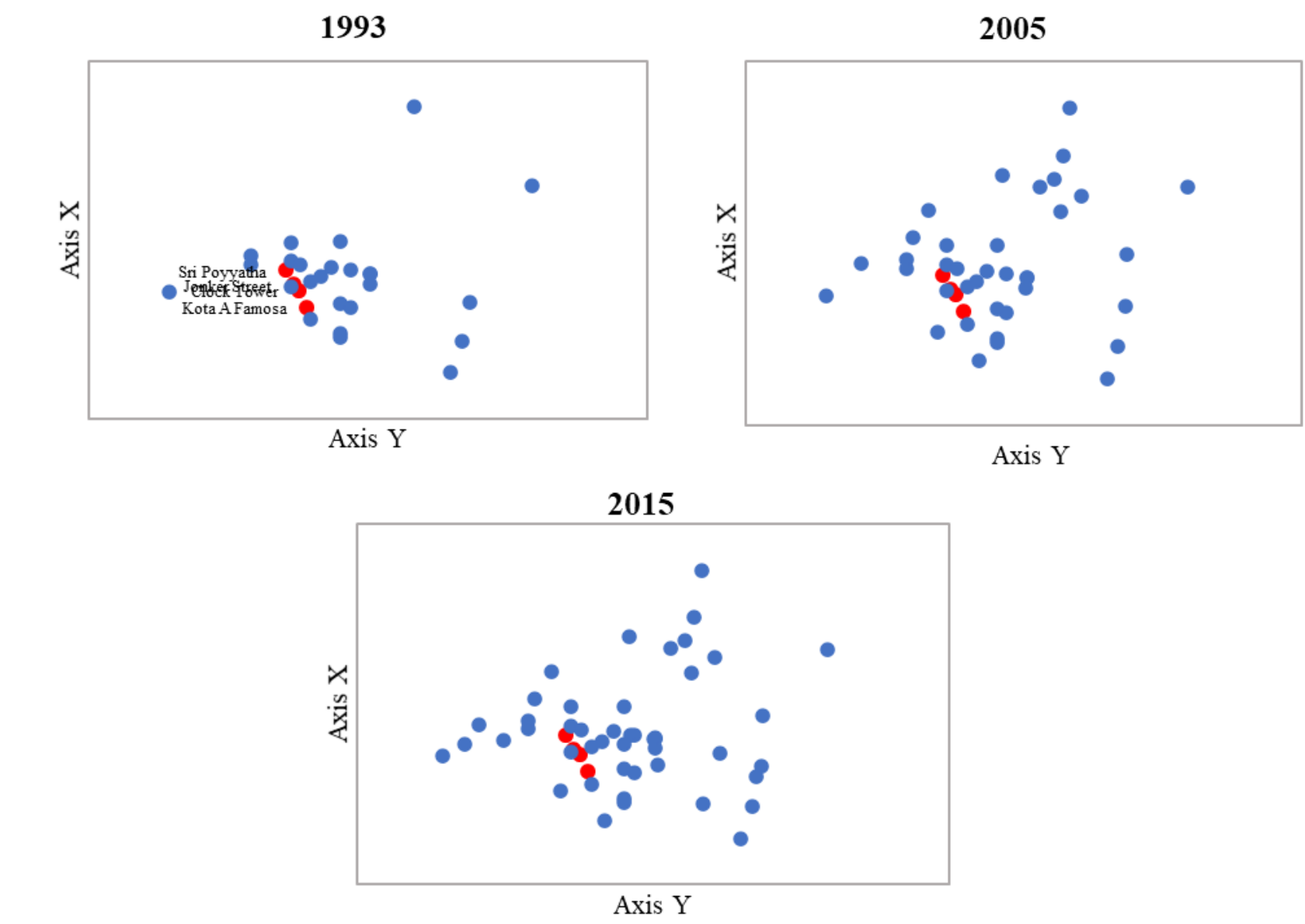

Axis $\mathrm{Y}$

Figure 11. Spatial distribution of street network for the years of 1993, 2005 and 2015. Source: Graph by the author, 2018 


\subsection{Cultural impact on the street development}

The formation and extensive use of regional and global networks have often been cited as reasons for the success of Chinese merchants in Southeast Asia [21-27]. The urban spatial planning in Malacca was a clear and transparent concept that influenced the whole city layout by the Chinese. The Chinese merchants monopolized the hustling port in the town, which was crowded with shophouses. Several major divisions were marked by a grid, with a robust axis in the middle. Along the central axis, different functional layers were arranged from Malacca River to the west and inland. The Chinese quarters were divided into several sectors, including the old harbor, workshops, markets, the rich people's living quarters, the ordinary people's living quarters, and the temple complex. Widodo (2004) mentioned that docks and warehouses were located near the coast in the southwest direction ${ }^{[28]}$.

Meanwhile, the wealthy village wet was set up side by side along the coastline that gives privilege to them for easy access to trading purposes. In the northwest part, a vernacular kampong house is populated by different ethnic groups, namely Malay, Arabs, Sumatrans, Javanese, and common Chinese people. The metropolitan that adjacent to the river was preserved when all the buildings inside the fort were destroyed during the Dutch period (1641-1826). This leads to the development of urban fabric along the coastline, and it prevails in two types of street systems. First, the street was adjacent to the river with a waterfront pattern. This pattern was developed horizontally alongside the riverbank. Second, the grid pattern developed into large blocks. The diverse racial communities were in an array according to the grid in their specific blocks during the Dutch period. However, as time passed by, racial segregation became blurred, but racial influences on the urban fabric have remained. Shophouses that were built of bricks and roofed by tiles were arranged on both sides of the streets. These narrow buildings were extended from the main streets into interiors by constructing several courtyards. As a result, many interlaced alleys were formed within each block. Trading activities in the city were operated in open markets and shophouses on every main street ${ }^{[29]}$.

\section{CONCLUSION}

Heritage street network patterns stand as the last remaining characteristics of past architecture style, so it is for Malacca city. The development of diverse multi-ethnic and culture due to maritime activities and intermarriages since the Sultanate of Malacca era has been a decisive factor and impact on the city's transformation. The expansion of the street networks in the inner-city from the years of 1993, 2005, and 2015 was immensely significant to the urbanization of Malacca. From this perspective, one may conclude that the existing street network has been evolved, not only in the physical structure, but also in cultural transformation that has influenced the cultural attributes of the streets. The attributes of the streets are exponential growth through the changes of power by providing a sense of place, which are affecting the human feelings and perceptions of the streets. Besides, due to the long process of trading port, the streets and cityscape of Malacca were divided based on the socio-economic, cultural and ethnic lines. The influence of ruling class or aristocracy plays an essential role in designing the city. Therefore, the influence of Dutch and Chinese architectural styles of the buildings reflects the characteristics of the streets and relates to the sense of place in tangible and intangible cultural heritage. Thus, Malacca's Chinatown is interpreted through the street characteristics and ambience. Overall, the China-Malacca relationship since the Sultanate era has been an outstanding contribution to spatial planning, cityscapes, and the emergence of a new ethnic group of Chinese Peranakan or "Baba and Nyonya."

\section{ACKNOWLEDGMENTS}

The authors greatly acknowledge the Malaysian Space Agency (MYSA) and PLANMalaysia for providing invaluable data used in this study. The authors sincerely thank 
all referees for their suggestions to improve the manuscript.

\section{FUNDING}

The research received no specific grant from any funding agency in the public, commercial, or not-for-profit sectors.

\section{CONFLICT OF INTEREST}

The authors declare no conflicts of interest.

\section{AUTHOR CONTRIBUTIONS}

M.M.N. was responsible for data collection, processing, analysis, and original manuscript writing. Meanwhile, N.M.N. was responsible for manuscript conception, as well as jointly writing and reviewing the draft. S.S. guided the overall research and revised the manuscript.

\section{REFERENCES}

[1] Conzen MRG. Alnwick, Northumberland: A study in town-plan analysis. 1969, Institute of British Geographers, London.

[2] Jacobs A. Great Streets. 1993, MIT Press, Cambridge.

[3] Cheng J. Exploring urban morphology using multi-temporal urban growth data: A case study of Wuhan, China [J]. Asian Geographer, 2011, 28(2): 85-103.

[4] Shpuza E. Allometry in the syntax of street networks: Evolution of Adriatic and Ionian coastal cities [J]. Environment and Planning B: Planning and Design, 2014, 41(3): 450-471.

[5] $\mathrm{Yu} \mathrm{B}$, Liu H, Wu J, et al. Investigating impacts of urban morphology on spatiotemporal variations of solar radiation with airborne LIDAR data and a solar flux model: A case study of downtown Houston $[\mathrm{J}]$. International Journal of Remote Sensing, 2009, 30(17): 43594385.

https://doi.org/10.1080/0143116080255 5846

[6] Farrell K. The rapid urban growth triad: A new conceptual framework for examining the urban transition in developing countries [J]. Sustainability
(Switzerland), 2017, 9(8): 1-19. https://doi.org/10.3390/su9081407

[7] Boeing G. Urban spatial order: Street network orientation, configuration, and entropy [J]. SSRN Electronic Journal, 2018 , $1-19$. https://doi.org/10.2139/ssrn.3224723

[8] Nor MM, Mohd Noor N. Integrating satellite temporal analysis for urban morphology study [J]. IOP Conference Series: Earth and Environmental Science, 2018, 169(1). https://doi.org/10.1088/17551315/169/1/012028

[9] Kropf K. Urban tissue and the character of towns [J]. Urban Design International, 1996, 1(3): 247-263. https://doi.org/10.1057/udi.1996.32

[10] Noor NM, Abdullah A. Sustainable urban planning mapping using remote sensing and GIS in Malaysia [J]. Joint Urban Remote Sensing Event, 2015, 1-4. https://doi.org/10.1109/JURSE.2015.71 20539

[11] Seok-Joon H. The social formation and cultural identity of Southeast Asian frontier society: Focused on the concept of maritime Zomia as frontier in connection with the ocean and the inland [J]. Journal of Marine and Island Cultures, 2016, 5(1): 28-35. https://doi.org/10.1016/j.imic.2016.05.0 04

[12] Wong DTK. (2017). Early Chinese presence in Malaysia as reflected by three cemeteries (17th-19th c.) [J]. Archipel, 92: 9-21. https://doi.org/10.4000/archipel.280

[13] Abdullah S. Effect of Malay-China trade relations during the Malacca Sultanate on the emergence of Chinese Peranakan community [J]. World Journal of Islamic History and Civilization, 2013, 3(4): 143-149.

[14] Yasin Z, Tan ASH, Abdullah AL, et al. The ocean legacy of Malaka and sustainability in the Straits of Malacca [J]. Journal of Ocean \& Culture, 2019, 2: 58-73. https://doi.org/10.33522/joc.2019.2.58 
[15] Jabatan Ketua Menteri Melaka. Pelan Strategik Melakaku Maju Jaya 2035. 2021, viewed on 5 July 2021, https://psmj2035.melaka.gov.my

[16] Qing M. A historic research on the architecture of Fujianese in the Malacca. Straits: Temple and Huiguan [T]. 1999, The Chinese University of Hong Kong. https://repository.lib.cuhk.edu.hk/en/ite m/cuhk-323093

[17] Chee-Beng T. Chinese identities in Malaysia [J]. Southeast Asian Journal of Social Science, 1997, 25(2): 103-116. Retrieved October 16, 2020, from http://www.jstor.org/stable/24492399

[18] Lockard CA. "The sea common to all": Maritime frontiers, port cities, and Chinese traders in the Southeast Asian age of commerce, ca. 1400-1750 [J]. Journal of World History, 2010, 21(2): 219-247. https://doi.org/10.1353/jwh.0.0127

[19] De Witt D. Melaka from the top. 2010, Nutmeg Publishing.

[20] Jabatan Perancang Bandar \& Desa (JPBD) Pulau Pinang. Special Area Plan Georgetown. 2011.

[21] UNESCO. Conversation management plan and special area plan. 2011. Retrieved from https://whc.unesco.org/en/list/1223/doc uments/

[22] Foody GM. Status of land cover classification accuracy assessment [J]. Remote Sensing of Environment, 2002, 80(1):

185-201.
https://doi.org/10.1016/S0034-

4257(01)00295-4

[23] Rahman NA, Shamsuddin S, Ghani I. What makes people use the street?: Towards a liveable urban environment in Kuala Lumpur city centre [J]. ProcediaSocial and Behavioral Sciences, 2015, 170: 624-632.

[24] Goldberg MA. The Chinese connection: Getting plugged in to Pacific Rim real estate, trade, and capital markets. 1985, University of British Columbia Press, Vancouver.

[25] Yoshihara K. Philippine industrialisation: Foreign and domestic capital. 1985, Oxford University Press, Singapore.

[26] Menkoff T, Labig CE. Trading networks of Chinese entrepreneurs in Singapore [J]. Journal of Social Issues in Southeast Asia. 1996, 2(1): 128-151.

[27] Landa JT. The law and bioeconomics of ethnic cooperation and conflict in plural societies of southeast Asia: A theory of Chinese merchant success [J]. Journal Bioeconomics, 1999, 1: 269-284.

[28] Widodo J, Chinese Heritage Center (Singapore). The Boat and the city: Chinese diaspora and the architecture of Southeast Asian coastal cities. 2004, Marshall Cavendish Academic.

[29] Han W, Beisi J. Urban morphology of commercial port cities and shophouses in Southeast Asia [J]. Procedia Engineering, 2016, 142: 190-197. https://doi.org/10.1016/j.proeng.2016.02 .031 